\title{
Water Runoff Estimation Using Geographical Information System (GIS) for Alrakhmah Basin Valley Northeast of Iraq
}

\author{
Abdulrazaq K. Abdulwahd1, Mohammed Ch. Liejy¹, Mohanad A. Sulaiman², Nadhir Al-Ansari3 ${ }^{3}$ \\ ${ }^{1}$ Technical Institute of Haweeja, Northern Technical University, Kirkuk, Iraq \\ ${ }^{2}$ General Commission for Running/Irrigation and Drainage, Kirkuk Province, Ministry of Water Resources, Kirkuk, Iraq \\ ${ }^{3}$ Lulea University of Technology, Lulea, Sweden \\ Email: abd.kder@yahoo.com, chyd1982@gmail.com, amohanad98@yahoo.com, *nadhir.alansari@ltu.se
}

How to cite this paper: Abdulwahd, A.K., Liejy, M.Ch., Sulaiman, M.A. and Al-Ansari, N. (2020) Water Runoff Estimation Using Geographical Information System (GIS) for Alrakhmah Basin Valley Northeast of Iraq. Engineering, 12, 315-324.

https://doi.org/10.4236/eng.2020.126025

Received: May 4, 2020

Accepted: June 6, 2020

Published: June 9, 2020

Copyright $\odot 2020$ by author(s) and Scientific Research Publishing Inc. This work is licensed under the Creative Commons Attribution International License (CC BY 4.0).

http://creativecommons.org/licenses/by/4.0/

\begin{abstract}
The lack of water resources in many regions is the main challenge for the human being and to extended investigations. Water resources controlling and management is essential in the areas depending on the seasonal rainfall. This research aims to estimate the surface water runoff for Basin of Alrakhmah Valley located in the southwestern part of Kirkuk Province in northeastern of Iraq. Analyzing of Spatial data and Digital Elevation Model (DEM) data has been conducted using Geographic Information System (GIS) to estimate the hydrological properties for the watershed valley with $158.5 \mathrm{~km}^{2}$ surface area. The results showed that watershed valley type is from the fifth rank with a longitudinal shape and topography percentage of 0.568 . The watershed textures found to be 3.24 and the drain density 1.5 at 3.49 river branching. Finally, the annual estimated surface water retreat according to the morpho-hydro climatic elements found to be 0.01286233 milliard cubic meter.
\end{abstract}

\section{Keywords}

Geographic Information Systems (GIS), Digital Elevation Model (DEM), Spatial Data, Watershed

\section{Introduction}

Water is one of the essential components of human life; however, many countries suffer from a severe shortage of water resources. This problem of water shortage threatens many areas in the world. The increased dry and semi-dry areas that need water to invest in development operation in these regions make researchers focus on the amount of runoff in these areas; especially these lacked 
hydrometric station to measure the amount of surface water depending on the relationship between the rain and runoff to estimate the water amount which could be invested [1]. The present research studies the surface hydrology of Al-Rakhmah Valley using GIS. The importance and justification of the research come from studying hydrological undiscovered water basins to discover the resources of surface water [2]. These resources have become a necessity that should be emphasized to achieve the total development of water resources in the country particularly in a time of the weakening of future water imports from the Tigris and Euphrates rivers [3].

The possibility of analyzing space data and digital elevation model data (DEM) is an important source in taking out some hydrological and geological properties of the water basin in the study area as an alternative to topographic maps [1] [4]. Therefore, this research aims to identify the hydrological properties of the basin of the study area and estimates the amount of the runoff through the use of (Arc GIS) program, as well as the use of the digital elevation model (DEM).

\section{Methodology}

The location of Al-Rakhma Valley in Zab sub-district was chosen, it locates in the southwest of Kirkuk province, in the northeastern part of Iraq between longitudes $\left(22^{\circ}-43^{\circ}\right.$ and $\left.30^{\circ}-43^{\circ}\right)$ east and two latitudes $\left(18^{\circ}-35^{\circ}\right.$ and $\left.28^{\circ}-35^{\circ}\right)$ north. The estimated study area is (158.5) Kilometers. The basin is bordered from the east by the water-splitting line with Al-Fada Valley, as shown in Figure 1. On the west side, which is considered as the opening of the basin, is agricultural land and the village of Adbis, which is connected with the Tigris River. From the south bordered with the administrative border of Zab sub-district to the north, it is bordered by agricultural land that is connected to the Karkh Gokh in Makhmoor.

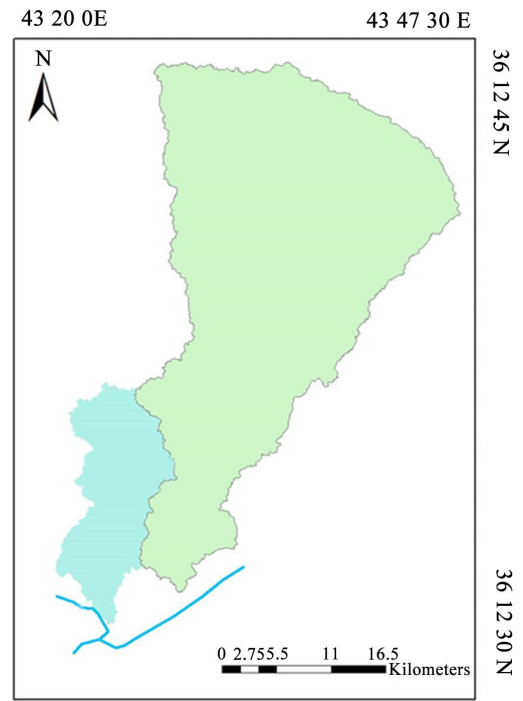

Figure 1. Location for the Basin of Alrakmah valley. 
Research steps have prepared depending on (GIS 10.2), extraction the nutrition basin (Watershed), paths network of valley discharge (Stream order) through (ark Hydro-GIS). For the study area from the digital elevation file which also known as radar data (DEM) with a distinguishing accuracy (30 meters) taken from the American Geological Space (USGS) from radar shuttle (SRTM) [5] as shown in Figure 2.

The climate is one of the most important hydrological elements in terms of water nutrition and the amount of water discharge, identification of high discharges and periods of delay so that the interest in climate data analysis [6]. The temperature, rain, relative humidity and wind speed prevailing in the area have a direct effect on the amount of surface runoff and surface forms of the earth. The climate data depended on the study [7] were used to analyze the climatic data for the study area in the period 1980-2008 according to the FAO Panaman-Monteith equation using the CropWat version 8.0 [8] as shown in Table 1. The climate of the study area falls within the semi-dry hot summer.

The evapotranspiration value extraction by the FAO Panaman-Monteith using computer program (CropWat version 8.0) [9] as shown in Table 1 and as follows:

$$
E T_{o}=\frac{0.408 \Delta(R n-G)+\gamma \frac{900}{T+273} U_{2}\left(e_{s}-e_{a}\right)}{\Delta+\gamma\left(1+0.34 U_{2}\right)}
$$

where:

Table 1. The monthly and annual water balance of the station of the study area.

\begin{tabular}{|c|c|c|c|c|c|c|c|c|}
\hline Month & $\begin{array}{c}\text { Average } \\
\text { temperature }\end{array}$ & $\begin{array}{l}\text { Relative } \\
\text { humidity }\end{array}$ & $\begin{array}{l}\text { Wind } \\
\text { speed }\end{array}$ & $\begin{array}{l}\text { Hours of solar } \\
\text { brightness }\end{array}$ & Evaporation & Evaporation & Rain & $\begin{array}{l}\text { Surplus } \\
\text { shortage }\end{array}$ \\
\hline & ${ }^{\circ} \mathrm{C}$ & $\%$ & $\mathrm{~m} / \mathrm{sec}$ & Hour & $\mathrm{Mm} /$ day & $\mathrm{Mm} / \mathrm{month}$ & $\mathrm{Mm} /$ month & $\mathrm{Mm} /$ month \\
\hline January & 7.5 & 86 & 0.9 & 4.7 & 0.82 & 25.42 & 58.90 & 33.48 \\
\hline February & 8.6 & 77 & 1.3 & 5.6 & 1.3 & 36.4 & 59.10 & 22.70 \\
\hline March & 12.6 & 71 & 1.2 & 6.4 & 2.01 & 62.31 & 70.70 & 8.39 \\
\hline April & 23.5 & 63 & 1.4 & 7.5 & 3.84 & 115.2 & 46.80 & -68.40 \\
\hline May & 25.2 & 48 & 1.6 & 9.8 & 5.35 & 165.85 & 15.10 & -150.75 \\
\hline June & 31.1 & 28 & 1.7 & 10.8 & 6.9 & 207 & 1.40 & -205.60 \\
\hline July & 34.2 & 26 & 1.8 & 11.1 & 7.56 & 234.36 & 0.20 & -234.16 \\
\hline August & 33.7 & 27 & 1.5 & 11 & 6.76 & 209.56 & 0.00 & -209.56 \\
\hline September & 29.7 & 32 & 1.1 & 10.9 & 5.11 & 153.3 & 0.30 & -153.00 \\
\hline October & 22.4 & 48 & 0.7 & 8.6 & 2.93 & 90.83 & 13.20 & -77.63 \\
\hline November & 14.1 & 64 & 0.6 & 5.5 & 1.47 & 44.1 & 49.40 & 5.30 \\
\hline December & 9.3 & 79 & 0.8 & 4.3 & 0.9 & 27.9 & 69.00 & 41.10 \\
\hline General rate & 21 & 54 & 1.2 & 8 & 3.75 & 1143525 & 32.01 & \\
\hline Annual total & & & & & & 1372.23 & 384.10 & \\
\hline
\end{tabular}




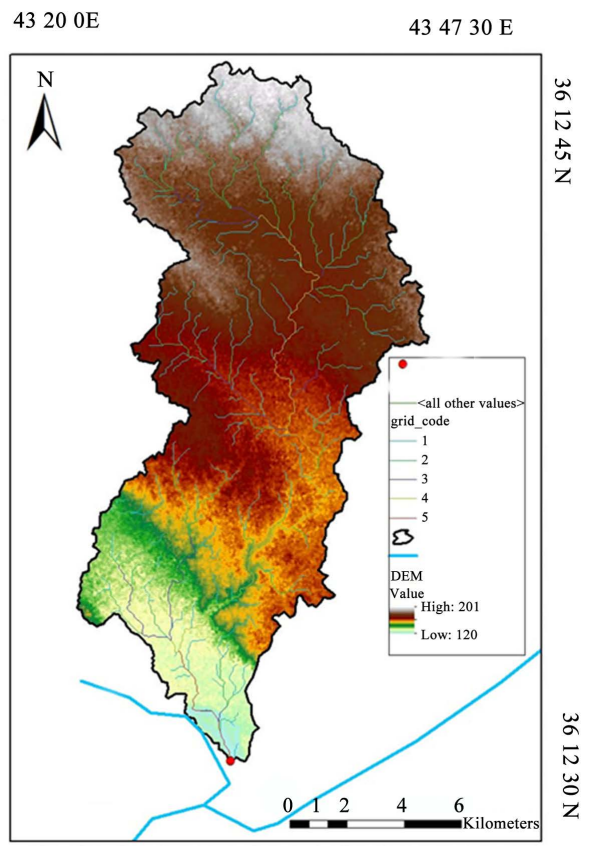

Figure 2. Recharge basin and the valleys of Al-Rakhmah Valley, based on the digital elevation model and the GIS program.

$E T_{o}$ represents Evaporation - Nectar Reference ( $\mathrm{mm} /$ day)

$\Delta$ represents Equilibrating Mileage of Steam Pressure Saturation $\left(\mathrm{kPa} / \mathrm{m}^{\circ}\right)$

$R n$ represents Net Solar Radiation (mica joule $/ \mathrm{m}^{2}$ day)

$T$ represents Average Daily Temperature $\mathrm{m}^{\circ}$

$U_{2}$ represents Wind Speed $\mathrm{m} / \mathrm{sec}$

$\left(e_{s}-e_{a}\right)$ represents Decrease in Saturated Steam Pressure $(\mathrm{kPa})$

$e_{s}$ represents Steam Pressure Saturation $(\mathrm{kPa})$

$e_{a}$ represents Actual Steam Pressure $(\mathrm{kPa})$

$G$ represents Soil Temperature Density (mica Joule $/ \mathrm{m}^{2}$ day)

$\gamma$ represents Wet Measurement Constant (kilo $\mathrm{Pa} / \mathrm{m}^{\circ}$ )

Surface water flow is defined as the part of the rainwater that exceeds the absorbent capacity of the soil and moves on the surface of the earth, taking several paths according to the geomorphology of the earth and its slope until it reaches a sewer and becomes part of it [10]. Because the basin is not observed, and no water flow readings are available, the Berkeley Experimental Equation has been used to determine the expected annual runoff [11]. The equation is based on two variables: the climatic data of the region and the morphometric characteristics of the basin, while the surface water flow factor was extracted according to the equation of [12], it was (0.196), and Berkeley's equation is as the following formula:

$$
R=(C I S)^{0.5}\left(\frac{W}{L}\right)^{0.45}
$$

where:

$R=$ Annual flow rate that expected to be 1 billion $\mathrm{m}^{3}$

$C=$ Surface water flow Factor 
$I=$ Rain volume 1 billion $\mathrm{m}^{3}$

$S=$ Regression rate $(\mathrm{m} / \mathrm{km})$

$W=$ basin width rate $(\mathrm{km})$

$L=$ valley length (from upstream to downstream) $\mathrm{km}$

While the Khoslais equation is the following formula [12]:

$$
\begin{aligned}
R_{m} & =P_{m}-L_{m} \\
L_{m} & =0.48 T_{m}
\end{aligned}
$$

where;

$$
\begin{aligned}
& R_{m} \leq 0 \\
& L_{m}=0.48 T_{m} \\
& T_{m}>4.5^{\circ} \mathrm{C}
\end{aligned}
$$

That is

$R_{m}$ : Monthly surface water flow $(\mathrm{cm})\left(R_{m} \geq 0\right)$

$P_{m}$ : Monthly rainfall $(\mathrm{cm})$

$L_{m}$ : Monthly missing $(\mathrm{cm})$

$T_{m}$ : monthly average temperature (percent)

\section{Results and Discussion}

Figure 3 shows the longitudinal section for the basin of Al-Rukhma Valley extracted from the environment (Arc GIS) from analysis (Analyst 3D). It is observed that the valley levels ranged from 120 meters to 201 meters. The area, perimeter, length and width of the basin are extracted, then made morphometric equations based on those basic elements and access to the morphometric properties.

A previous study for the basin of Al-Fadhah Valley which is aligned to the study area, it found that the soil domination texture in the basin of the study area from the upstream which represents the district 60 Shimeets to the estuary: is a clay gluten, it contains $35 \%$ of clay, $20 \%$ sand, $45 \%$ gluten, and the lime is $45 \%$. It is characterized by yellowish brown, porosity, which makes it, in turn,

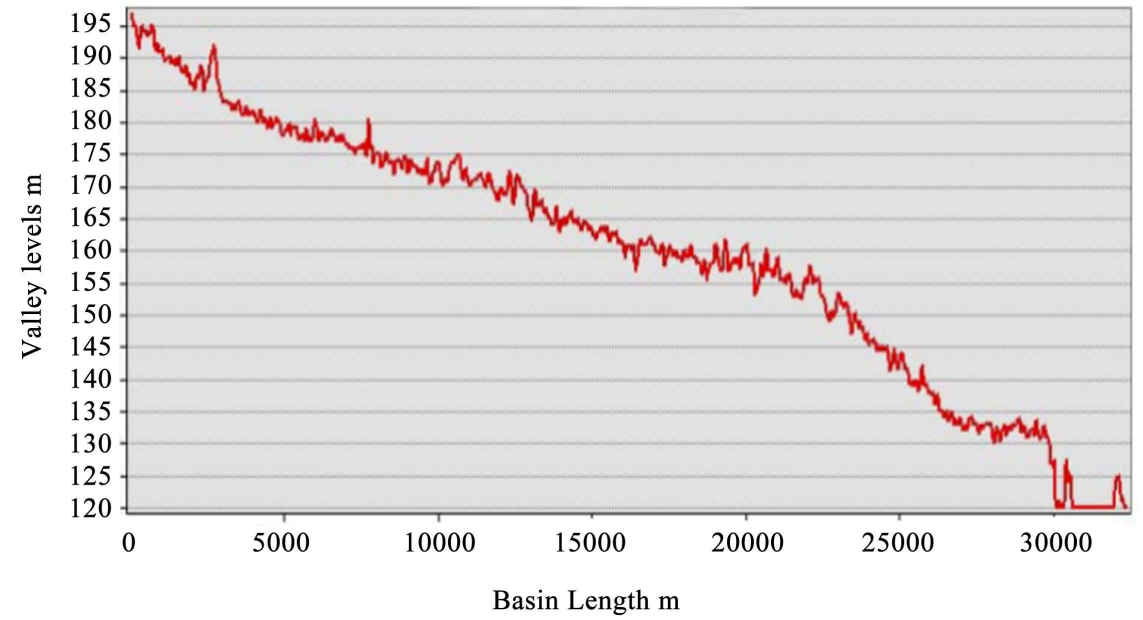

Figure 3. Longitudinal section for basin of Al-Rakhma valley. 


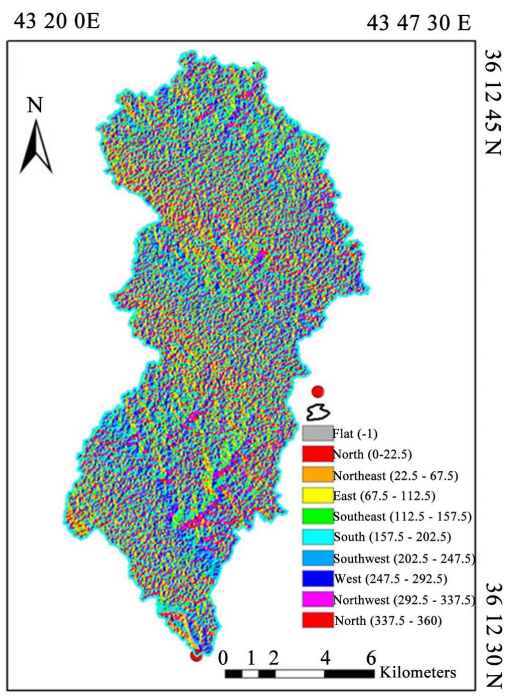

Figure 4. The trend of the usual slopes in the study area based on the digital height model and the GIS program.

reduces surface runoff and water retention. The area of study is known as the local erosion plains, the formation of Al-hamada, Al-sareer and residues of the valleys bottoms. There are wide tracts of land that overlap between the plateaus in the region, which is one of the best agricultural lands for the farming of wheat and barley, restricted from the rising line $(200 \mathrm{~m}-150 \mathrm{~m})$ above the sea level. The topographical situation in this basin varies between regions, poor land, lowlands and water bodies. Figure 4 shows the direction of the usual slopes for the basin of the study area, which is a type of representation of the topography of the study area. Figure 5 shows the trends of the topography for the Basin of Al-Rakhma Valley, the trends ranging between $0 \%-20 \%$ and the general average of tendencies $2.6 \%$. It is determined by analyzing the surface within the environment (a spatial analytical tool). In general, Al-Rakhma Valley is considered as an average slope.

Most of the rainfalls are concentrated in winter and spring, reduced in autumn and absence in summer, and the average annual rainfall $(384.1 \mathrm{~mm})$, the study area is restricted between rain lines $400-300 \mathrm{~mm}$. It is characterized by variations in monthly and annual rates, as well as the study area is characterized by the length of the period of drought. It noticed that there is according in dropping of temperature with the season of rainfall, which leads to low evaporation efficiency so that an increase in the value of rain and this leads to seasonal water runoff. The total annual evaporation at the station of the study area found to be $1372.23 \mathrm{~mm}$, where the highest evaporation value in July accorded with an increase in temperature. In a comparison of the effect of evaporation with rain shows that there was a water surplus $(110.97 \mathrm{~mm}$ ) during the months (November, December, January, February and March). The other seven months were characterized by water shortage, and they represented in negative values in Table 1. Annual shortage found to be $1099.1 \mathrm{~mm}$, here the groundwater feeds the area, in addition to springs and fountains in the basin. 


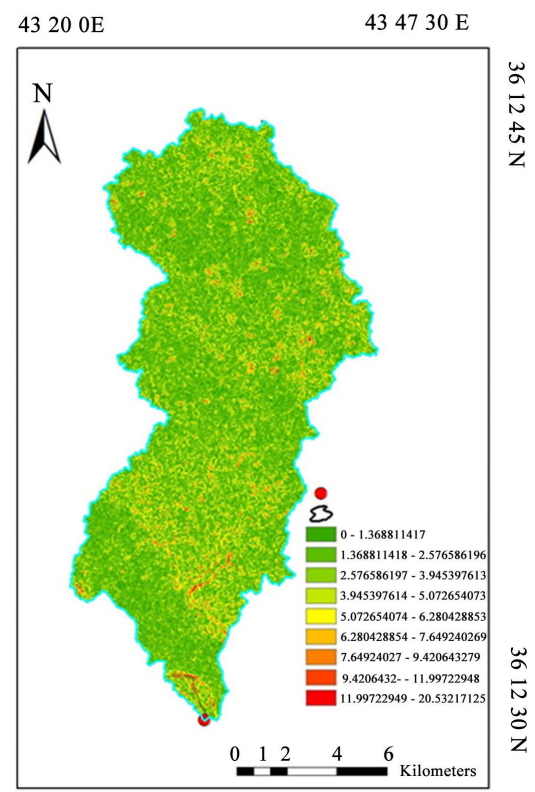

Figure 5. Trends in the study area basin based on digital height model and GIS program.

The morphometric results were obtained, as shown in Table 2 from the digital elevation model (DEM) of the basin depicted in Figure 6. In addition to the calculations of descriptive data (attribute Table) within the environment of the GIS program. Table 2 shows clearly that the Basin of Al-Rakhma Valley has properties of form close to the rectangle for the low factor value of form (0.25), and the elongation ratio was $(0.568)$. While the terrain characteristics recorded low values (3.24) $\mathrm{m} / \mathrm{km}$, due to the decrease of the terrain Valley spring $(201 \mathrm{~m})$, with the lowest point in the valley $120 \mathrm{~m}$. In terms of drainage characteristics, it is clear that the basin of Al-Rakhma Vally is fifth grade.

Using Equation (2) according to the climatic and morphometric data of the basin of the study area, as it is shown in Table 3, it was found that the total annual surface water flows (0.01286233) Billion m3. It is important to estimate the amount of the expected annual flow of water to know the erosion, sediment and drifting of the running water in the valley and its effect on the formation of the earth's surface appearances. Furthermore, investing these quantities through the application of rainwater harvesting technology and constructs small barriers and dams on certain sites of the valley instead of wasting them and going to land Causing damage to cultivated crops in the area and closing roads until rainwater retreated.

Using Equation (3) and (4) for Khoslais formula

Example Jan. month

From Table $1 P_{m}=(58.9 \mathrm{~mm} / 10)=5.89 \mathrm{~cm}$ and $T_{m}=7.5^{\circ} \mathrm{C}$

$$
\begin{gathered}
L_{m}=0.48 \times 7.5=3.6 \mathrm{~cm} \\
R_{m}=5.89-3.6=2.29 \mathrm{~cm}
\end{gathered}
$$

Annual Surface Runoff $=2.29+1.782+1.022+2.436=7.53 \mathrm{~cm}^{3}$

Annual Surface Runoff Factor $=7.53 / 38.41=0.196$ (Table 4) 
Table 2. Calculated values of Morphometric properties for the Basin of Al-Rakhma Valley.

\begin{tabular}{cc}
\hline Morphometric properties & Values \\
\hline Area of the basin $\left(\mathrm{km}^{2}\right)$ & 158.5 \\
Circumference of the basin $(\mathrm{km})$ & 85 \\
Basin width $(\mathrm{km})$ & 8 \\
Length of basin $(\mathrm{km})$ & 25 \\
Incubation degree $(\mathrm{m} / \mathrm{km})$ & 3.24 \\
The highest point in the aquarium $\mathrm{m}$ & 201 \\
The lowest point in the aquarium & 120 \\
Number of riverbeds & 5 \\
Total length of waterways $(\mathrm{km})$ & 236.5 \\
Total number of valleys & 297 \\
Density of discharge $\left(\mathrm{km} / \mathrm{km}{ }^{2}\right)$ & 1.5 \\
River frequency $($ valley/km) & 3.49 \\
Coefficient of pelvic shape & 0.25 \\
Bifurcation ratio & 1.98 \\
Elongation rate $(\mathrm{km} / \mathrm{km})$ & 0.568 \\
Constant survival of the stream & 0.666 \\
\hline
\end{tabular}

Table 3. Monthly surface salinity values according to Khoslais Equation.

\begin{tabular}{cccc}
\hline Months & $L_{m}=0.48 T_{m}$ & $P_{m}$ & $R_{m}=P_{m}-L_{m}$ \\
\hline Jan. & 3.6 & 5.89 & 2.29 \\
Feb. & 4.128 & 5.91 & 1.782 \\
March & 6.048 & 7.07 & 1.022 \\
April & 11.28 & 4.68 & -6.6 \\
May & 12.096 & 1.51 & -10.586 \\
June & 14.928 & 0.14 & -14.788 \\
July & 16.416 & 0.02 & -16.396 \\
August & 16.176 & 0 & -16.176 \\
September & 14.256 & 0.03 & -14.226 \\
November & 10.752 & 1.32 & -9.432 \\
October & 6.768 & 4.94 & -1.828 \\
December & 4.464 & 6.9 & 2.436
\end{tabular}

Table 4. The expected annual water flow of the water drainage network for the Basin of Al-Rakhma Valley.

\begin{tabular}{ccccccc}
\hline $\begin{array}{c}\text { Flow size } \\
\text { Annual forecast } \\
\text { (Billion cubic meters) }\end{array}$ & $\begin{array}{c}\text { size } \\
\text { Annual Rain } \\
\text { (Billion cubic meters) }\end{array}$ & $\begin{array}{c}\text { Rate } \\
\text { the rain } \\
\text { Annual }(\mathrm{mm})\end{array}$ & $\begin{array}{c}\text { space } \\
\text { The aquarium } \\
\left(\mathrm{km}^{2}\right)\end{array}$ & $\begin{array}{c}\text { Rate } \\
\text { Regression } \\
(\mathrm{M} / \mathrm{km})\end{array}$ & $\begin{array}{c}\text { View rate } \\
\text { The aquarium } \\
\text { (How many) }\end{array}$ & $\begin{array}{c}\text { Length } \\
\text { The aquarium } \\
(\text { How many) }\end{array}$ \\
\hline 0.01286233 & 0.06087 & 384.1 & 158.5 & 3.24 & 8 & 25 \\
\hline DOI: $10.4236 /$ eng.2020.126025 & & 322 & & Engineering
\end{tabular}




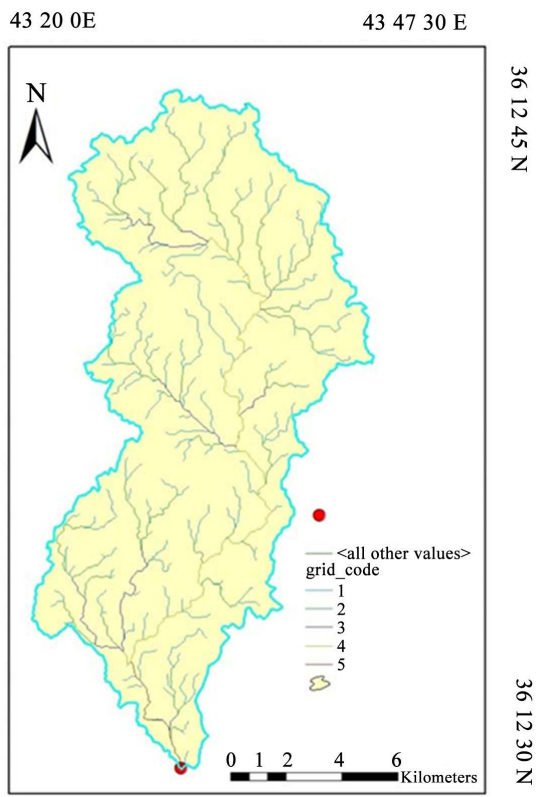

Figure 6. Al-Rakhma Valley waterway network based on digital elevation model and GIS program.

\section{Conclusions}

In this study, investigation of the water basin and analyses of morphometric properties of the basin using GIS technology was carried out. Rakham Valley is considered in this case. It has five river mattresses; total ducts are 297 streams within the area of $158.5 \mathrm{~km}^{2}$ and its circumference $85 \mathrm{~km}$. The main finding can be summarized as follows:

1) The Basin of Al-Rakhma Valley has shape properties close to the rectangle for decreasing in the value of the form factor (0.25) also the elongation ratio (0.568). However, the terrain's properties record the lowest point $3.24 \mathrm{~m} / \mathrm{km}$, due to the low erosion of the Valley source $(201 \mathrm{~m})$, with the lowest point in the valley $(120 \mathrm{~m})$. According to drainage characteristics it is clear that the basin of the valley is from the fifth rank.

2) The climate of the study area is drought with the water shortage in seven months. The maximum in July was $234.16 \mathrm{~mm}$ with surplus water during the months (November, January, January, February and March).

3) The expected annual runoff for the basin of the study area was estimated in consideration of climatic, morphometric variables, the surface factor (0.196) and using the Berkeley equation is (0.01286233) billion cubic meters.

4) Accordingly, we establish small barriers and dams on the valleys to take advantage of runoff water during the rainy period, which will contribute to developing the water resources in the area.

\section{Conflicts of Interest}

The authors declare no conflicts of interest regarding the publication of this paper. 


\section{References}

[1] Zollweg, J.A., Gburek, W.J. and Steenhuis, T.S. (1996) SMoRMod-A GIS-Integrated Rainfall-Runoff Model. Transaction of the ASAE, 39, 1299-1307.

https://www.researchgate.net/publication/274489010_SMoRMod_-_a_GIS-integrat ed_rainfall-runoff_model https://doi.org/10.13031/2013.27621

[2] Dhawale, A.W. (2013) Runoff Estimation for Darewadi Watershed Using RS and GIS. International Journal of Recent Technology and Engineering (IJRTE), 1, 46-50.

[3] Melesse, A. (2002) Spatially Distributed Storm Runoff Depth Estimation Using Landsat Images and GIS. Computers and Electronics in Agriculture, 37, 173-183. https://doi.org/10.1016/S0168-1699(02)00111-4

[4] Anbazhagan, S., Ramasamy, S.M. and Das Gupta, S. (2005) Remote Sensing and GIS for Artificial Recharge Study, Runoff Estimation and Planning in Ayyar Basin, Tamil Nadu, India. Environmental Geology, 48, 158-170.

https://doi.org/10.1007/s00254-005-1284-4

[5] EarthExplorer. (2015) World, USGS Science for Changing. https://EarthexplorerUsgsGov/Logout/Expire

[6] Gupta, K.K., Deelstra, J. and Sharma, K.D. (1997) Estimation of Water Harvesting Potential for a Semiarid Area Using GIS and Remote Sensing. Proceedings of Rabat Symposium S3 (April 1997) "Remote Sensing and Geographic Information Systems for Design and Operation of Water Resources Systems”, IAHS Publication No. 242, 53-62.

[7] Mahmoud, S.H. (2014) Investigation of Rainfall-Runoff Modeling for Egypt by Using Remote Sensing and GIS Integration. Catena, 120, 111-121. https://doi.org/10.1016/j.catena.2014.04.011

[8] Food and Agricultural Organization (2020) CropWat, Land and Water. http://www.fao.org/land-water/databases-and-software/cropwat/en/

[9] Allen, R.G., Ppereira, L.S., Raes, D. and Smith, M. (1998) Crop Evapotranpiration (Guidelines for Computing Crop Water Requirement), Food and Agriculture Organization of the United Nations (FAO), Irrigation and Drainage Paper, No. 56, Rome.

http://www.fao.org/tempref/SD/Reserved/Agromet/PET/FAO_Irrigation_Drainage _Paper_56.pdf

[10] Fernandez, C., Wu, J., McCool, D. and Stoeckle, C. (2003) Estimating Water Erosion and Sediment Yield with GIS, RUSLE, and SEDD. Journal of Soil and Water Conservation, 58, 128-136.

[11] de Winnaar, G., Jewitt, G.P.W. and Horan, M. (2007) A GIS-Based Approach for Identifying Potential Runoff Harvesting Sites in the Thukela River Basin, South Africa. Physics and Chemistry of the Earth, 32, 1058-1067. https://doi.org/10.1016/j.pce.2007.07.009

[12] Batelaan, O. and De Smedt, F. (2007) GIS-Based Recharge Estimation by Coupling Surface-Subsurface Water Balances. Journal of Hydrology, 337, 337-355. https://doi.org/10.1016/j.jhydrol.2007.02.001 